\title{
Personal Values and The Level of Satisfaction on Institutional Education System Among
}

\section{International Students}

\author{
Iin Rachmawati ${ }^{1}$ \\ STKIP PGRI Bangkalan ${ }^{1}$ \\ iinrachmawati@gmail.com / iinrachma@stkippgri-bkl.ac.id
}

Iin Rachmawati, STKIP PGRI Bangkalan

\begin{abstract}
ABSTRAK
Universitas Airlangga telah dikenal luas sebagai salah satu tujuan pendidikan tinggi bagi para siswa internasional untuk belajar tentang Bahasa Indonesia. Baru-baru ini, isu yang berkaitan dengan penggunaan bahasa Inggris sebagai lingua franca untuk mengajar siswa internasional tentang Bahasa Indonesia telah mendapatkan banyak sekali perhatian dari kalangan akademisi. Lebih dari itu, memiliki siswa internasional berarti bahwa suatu universitas dituntut untuk bisa memberikan harapan serta tanggung jawab yang lebih besar. Dalam kasus semacam ini, siswa-siswa internasional tersebut mungkin saja akan mengalami beberapa perbedaan dalam hal sistem pendidikan dan pelayanan dalam kaitannya dengan nilai-nilai personal yang mereka miliki yang pastinya akan berbeda dengan negara tempat mereka belajar sekarang. Berdasarkan pada fakta-fakta itulah, penelitian ini bertujuan untuk menggali dan mengetahui lebih banyak tentang hubungan antara nilai-nilai personal dan derajat kepuasan terhadap institusi pendidikan dari siswa-siswa internasional yang sedang belajar di Fakultas Ilmu Budaya - Universitas Airlangga. Data akan dikumpulkan melalui kuesioner yang disebarkan secara online yang terdiri dari dua puluh pertanyaan dimana ada sepuluh pertanyaan tentang nilai-nilai personal dan sepuluh pertanyaan tentang derajat kepuasan terhadap institusi pendidikan. Analisis data personal dilakukan untuk menguji hubungan antara nilai-nilai personal dan derajat kepuasan terhadap institusi pendidikan dari siswa-siswa internasional dengan menggunakan metode penelitian kuantitatif deskriptif. Kemudian peneliti berniat akan menggali lebih jauh tentang setiap jawaban yang diberikan oleh siswa-siswa internasional tersebut dalam beberapa diagram tabel. Selain itu peneliti juga melakukan wawancara singkat dengan siswa-siswa internasional tersebut. Hasil penelitian menunjukkan bahwa nilai-nilai personal ternyata memiliki efek positif dalam hal derajat kepuasan terhadap sistem pendidikan institusi di Fakultas Ilmu Budaya - Universitas Airlangga.
\end{abstract}

Keywords:siswa internasional, nilai-nilai personal, derajat kepuasan, sistem pendidikan institusi

\begin{abstract}
Airlangga University has been recognized as one of higher education destinations for international students to learn more about Bahasa Indonesia. Recently, the issue of using English as a lingua franca to teach international students to learn more about Bahasa Indonesia has gained such enormous attention. However, dealing with the international students will significantly add additional expectations and responsibilities for the universities. In this case, those international students might experience some different educational systems and services in relation to their personal values in the host country as compared to their home country. Based on those facts, this research aims to explore and examine more about the relationship between personal values and the level of satisfaction on institutional education system among international students in Faculty of Humanity - Airlangga University. The data were gathered through an online questionnaire which contains for about twenty questions with
\end{abstract}


ten questions about personal values and ten questions about the level of satisfaction on institutional education system. Personal data analysis was performed to test the relationship between personal values and the level of satisfaction on institutional education system by using quantitative descriptive method. The researcher tends to examine more about each answer that has been given to the international students by showing the data in the table chart, and also doing some personal interviews to those students. The results revealed that personal values have a positive effect on the level ofsatisfaction on institutional education system among international students in Faculty of Humanity - Airlangga University.

Keywords:international students, personal values, level of satisfaction, institutional education system

\section{INTRODUCTION}

It can be said that international education is considered to be a raising phenomenon worldwide. The internationalization of higher education is one response to the driving force of globalization (Van Der Wende, 2007). The fact said that the international students tend to share a number of certain characteristics based on their personal background. Some studies have shown that international education generates financial benefits for the host countries (Benos and Zotou, 2014).

Basically, those international students will play certain roles in related to their choice of foreign institution. They will not only play as the ambassadors for their own country during their study, but they may also play on another ambassadorial role upon the completion of their study and stay. It is possible for those international students to encourage or discourage people in their social network to visit the country depending on their experiences during their study abroad (Jamaludin et al. 2016).

As they choose to study in a foreign institution, it is very important that they have to know English and Bahasa Indonesia in order to make sure that they have good understanding in following the class material. In this research, the researcher will begin to examine more about the relationship between personal values and the level of satisfactionon institutional education system among international students on Faculty of Humanity - Airlangga University.

Values are motivational goals that influence behaviors, attitudes, and evaluations (Fischer and Boer, 2016). Meanwhile, Schwartz et al. (2001) explains values as desirable, trans-situational goals of varying importance, which serve as guidelines for action. It is confirmed by Ferssizidis et al (2010) that personal values will influence human behavior, motivation, and goals. In other words, personal values will truly reflect what is very important to 
a person and as a consequence, it forms central part of an individual's identity which primarily guides the individual's action.

In order to gain a better understanding of international students' personal values, let's take a look at Schwartz's thought. Schwartz (2009) stated that people from Eastern Europe, Asia, Africa, and the Middle East tend to find meaning in life through social relationships and obeying expectations from those in roles of greater status or authority. As we have discussed about the international students, it is clear that there are some reasons for international students to choose an overseas study. Massey and Burrow (2012) found that the desire for a cross-cultural learning environment, followed by distinctive academic opportunity, and a unique social experience to be the main motivation of the incoming exchange students. All these findings are considered to be quite similar to some previous researches from Carlson (1990) and Sanchez et al. (2006) which has also found that cross-cultural reasons tend to exceed the academic or social reasons for studying abroad.

This research is mainly concerned with understanding more about personal values of the international students. It is expected that the results could give meaningful contribution to cross-cultural studies, especially about personal values and the level of satisfaction of the international students in learning abroad. It may become a side reading for many lecturers and provide useful information for the ordinary people who are interested in studying cross-cultural studies. By knowing the results of the relationship between personal values and the level of satisfaction of the international students, the researcher hopes that either lecturers or those ordinary people could understand more about crosscultural studies. The researcher also hopes that this research can make teachers or lecturers understand more about which part of the international students which tend to be increased and explored in order to gain their potential character and values as well as to gain their level of satisfaction about education abroad. And the most important thing is, after reading this research, the researcher hopes that the readers become more aware of cross-cultural studies in related to the international students who decide to study abroad for some reasons.

\section{International Students}

As a sojourner group, international students continue to grow in number worldwide, prompting researchers to study their global significance (Safdar and Berno, 2016). Based on the data from contemporary international education, there are two categories of students: shortterm students and long-term students. 
Short-term students are those who tend to stay for a few weeks to a whole year, mainly to gain some credits which may be transferred to their home university. Usually, these short-term students tend to have less experience in building the relationship among any other local students. And long-term students are students who often stay for long period of time, usually longer than a year to complete their academic degree at the overseas university. As they will stay for a long period of time, these long-term students tend to consider their new friends as their new family.

Both those short-term and long-term students have been stayed longer than those of an average tourist. That is why; it is really possible for them to have an opportunity to know the society better as well as to develop stronger loyalty intention. Of course, it is quite substantial to make sure that the element of personal values has been integrated well with the element of satisfaction level on the institutional education in order to create such good learning experience for the international students. By having good learning experience, it is really expected that those international students can gain the best academic grades as well as to reach the highest level on education.

\section{Personal Values}

As human beings, of course we have our own personal values, beliefs, and attitudes which we have been developed throughout our lives. It has already been discussed above that values are principles, standards, and qualities that a person or a group of people hold in high regard. For the next step, these values will guide our lives to any decisions that we make and how we are facing our lives. This is the main reason on why values can have such big influence to many of the judgments we make.

Actually, personal values can be seen through some points such as manners, pride, behaviors, family life, as well as about the choice on proper clothes. And for more information, it is really essential to know that personal values come from a variety of sources including family, peers, workplace, educational institutions, religion, music, media, culture, technology, major historical events (word war, economic depressions), or even based on some significant life events (deaths, divorce, major accident and trauma, losing jobs, financial losses, etc). Once you know exactly what your personal value is, it would be extremely important to develop an awareness of what you value as these values will be substantial in informing your relationship with people around you or with your environment (in the workplace, at school or college). 
The consciousness of our own personal value will be very important to help us to: ask ourselves about why we are doing what we are doing, to identify the consequences of our choices to ourselves and to someone else, and to consider about better options if possible. How we behave is a reflection of our beliefs and our beliefs are a reflection of our personal values.

This is the reason on the fact that each person may have different personal values based on some cultural backgrounds. These cultural backgrounds can include something like educational background, family background, religiousity, ethnicity, how they live their life, and many more external and internal factors.

\section{RESEARCH APPROACH}

In doing this research, the researcher uses quantitative descriptive method because the researcher uses the involvement of gathering data which describes events and then organizes, tabulates, depicts, and describes the data collection (Glass \& Hopkins, 1984). Moreover, this research uses description as a tool to organize the data into patterns which will emerge during data analysis. Most quantitative researches will usually fall into: studies which describe events and studies which aimed at discovering causal relationships. Primarily, descriptive studies will often be concerned with finding out 'what is' which makes the study to become observational and survey methods are frequently used to collect descriptive data (Borg \& Gall, 1989).

The major characteristic of this method is that it includes deductive process which means process from general to specific actions (Cresswell, 1994: 5). Another characteristic is that quantitative research is concerned with cause and effect. All the international students tend to do something because there are some factors or reasons on why they are doing what they are doing. This research is concerned with the use of English as a lingua franca in learning Bahasa Indonesia as well as to examine the relationship between personal values and the level of satisfaction on institutional education system among international students in Faculty of Humanity Airlangga University.

\section{Population and Sample}

Actually, population includes all members of a defined group, while sample is the subset of the population. The population of this research consists of all international students of Faculty of Humanity - Airlangga University Surabaya. There are four departments of S1 degree in Faculty of Humanity Airlangga University (English Department, Indonesian Department, Japanese Department, and History Department) and 
two departments of S2 degree Faculty of Humanity - Airlangga University (Master of Literature and Cultural Studies and Master of Linguistics Studies).

Moreover, there are three international students in Indonesian Department and they come from Malaysia, Senegal, and Australia. Moreover, there are two international students in Literature and Cultural Studies and they come from China and Kazakhstan. The sample of this research is taken from those two $\mathrm{S} 1$ and $\mathrm{S} 2$ departments. So, the total respondents will be five international students.

\section{DISCUSSION AND FINDINGS}

The findings said that every international student has their own characteristics based on their culture, religion, faith, and perspective in life. In terms of culture and religion, Malaysian student is the one who has the closest similarity with people in Indonesia. But again, it does not mean that she did not have any cultural shock in correlation with personal values and the level of satisfaction on Indonesian institutional education system. Furthermore, the level of cultural shock of that Malaysian student is just not as high and often as those who come from other countries with many different cultures from Indonesia, such as those from Australia, Senegal, China, and Kazakhstan.
There are three international students who come from non-speaking English country and they are including Serer student (from S2 Indonesian Department), Chinese student and Kazakhstani student (from S2 Literature and Cultural Studies). And they are two international students who come from English-speaking country: Malaysian student and Australian student.

Key to Understanding the Score of the Questionnaire

\begin{tabular}{|c|c|c|}
\hline Number & Measurement & Score \\
\hline 1 & Often / Always & 5 \\
\hline 2 & Generally & 4 \\
\hline 3 & Sometimes & 3 \\
\hline 4 & Seldom & 2 \\
\hline 5 & Never & 1 \\
\hline
\end{tabular}

The Relationship between Personal Values and the Level of Satisfaction on Indonesian Institutional Education System among the International Students

\section{MALAYSIAN STUDENT}

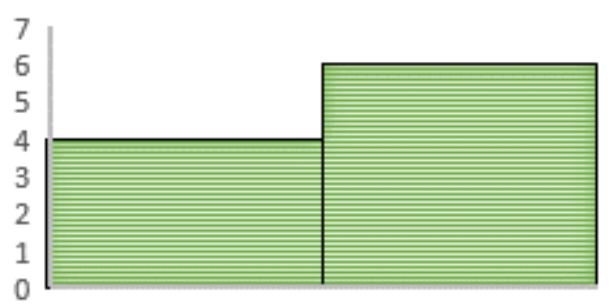

$[3,4,1]$

$(4,1,5,2]$ 
NB: Left Box (The Level of Satisfaction on Educational System) - Right Box

(Personal Values)

*Student from Malaysia is not too satisfied with Indonesian educational system

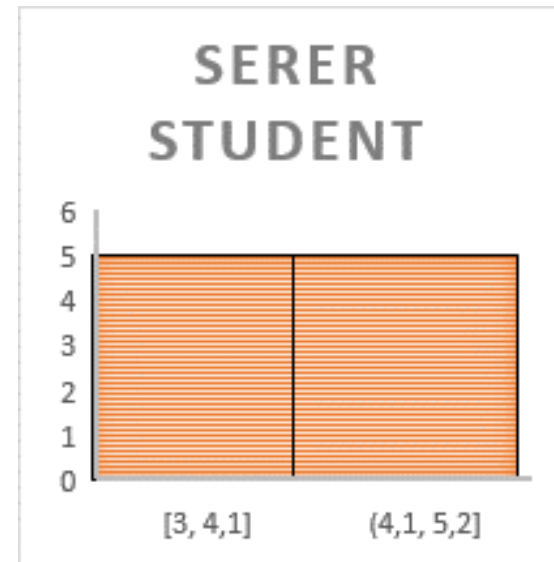

NB: Left Box (The Level of Satisfaction on Educational System) - Right Box (Personal Values)

*Student from Senegal has more hope on Indonesian educational system

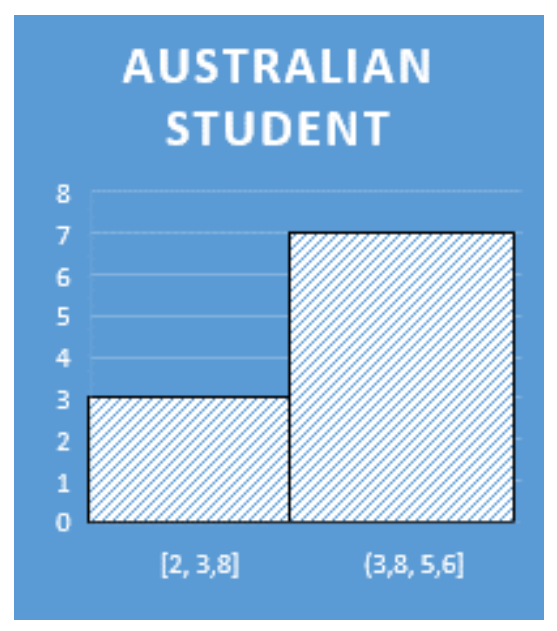

NB: Left Box (The Level of Satisfaction on Educational System) - Right Box (Personal Values)

*Student from Australia said that Indonesian educational system needs to be changed

1. Malaysian, Serer, and Australian Student (S1 Indonesian Department)

First of all, the researcher will begin the analysis from the Malaysian student who once said that she knows exactly about what personal values mean as well as its greater influence to her life and who'd she became now. She believes that her personal values influence the way she lives and the way she thinks about something. And some of the greatest influences on her are including the role of family life, religion, educational background, media, friends, and technology. Family life and her religion are the two most important things that build her character as she answers 'often/always' in the questionnaire. Besides that, she also believes that friends and the role of the media (whether it is mass media or social media) may have big influence on the process of building her perspective. Furthermore, the chance on getting higher education leads her to have better understanding on the technology so that 
she can manage on using the technology a lot more careful.

As Malaysia has been widely known as one of the most powerful countries in South East Asia, the researcher does not find any threaten regarding the role of some historical events happened to this Malaysian student. The same thing also happens when it comes to discuss about the role of workplace and some significant life events which are being answered as 'sometimes' on the questionnaire. And since the culture between Malaysia and Indonesia is almost similar where it is known that Indonesian culture is derived from Malayan culture, this Malaysian student stated that she does not want to change the Indonesian institutional education system even though she's not satisfied enough with the work of the lecturers and some educational staffs in Indonesia. And if it is compared to other international students whether from Indonesian Department or from Literature and Cultural Studies, this Malaysian student tends to get succeed in coming up with the cultural differences and educational system between Indonesia and her country as there is no significant boundaries.

Even though there are many similarities in culture between Malaysia and Indonesia, the data said that it does not mean that student from Malaysia can take the rules in
Indonesian educational system. Based on the data shown in the tabel above, it is clear that Malaysian student does not feel too satisfied with the whole Indonesian educational system. The left box has lower percentage than the right box which means that the relationship between personal values and the level of satisfaction on institutional education system is not too powerful.

Basically, the Malaysian student and the Serer student tend to consider that the biggest part of the personal values which influence their life most is about the role of the family life and their religion. Student from Senegal answers 'generally' on the role of the educational background, friends, and media to influence the way he chooses his life. And for the rest of the part of the personal values, he answers 'sometimes'. And the interesting part on this Serer student is about his perspective on the Indonesian educational system. Even though he has faced a lot of challenges in understanding English to learn Bahasa Indonesia as well as in coping with some cultural differences, he seems to feel satisfied enough with the whole institutional education system in Indonesia.

This surprising fact can be reviewed based on the educational background of the Serer student whose the institutional education system in Senegal tends to be less structured than Indonesian educational 
system. By the time he came to Indonesia, he considers feeling like he's home with a lot of easiness in transferring some of the college subjects.

Based on the data from the questionnaire, the Australian student tends to think that the role of the family life and technology are considered to be the biggest influence on her current life. If it is compared to Indonesia, Malaysia, or Senegal; it is quite clear that Australia had been fantastically developed on the modern technology and it is not surprised that the technology has been greatly influenced on its people. It does not mean that the role of the religion is not important as she answers it 'generally' on the questionnaire. The interesting part is about the fact that this Australian student answers 'sometimes' and 'seldom' for other parts of the personal values like the role of educational background, friends, historical events, some significant life events, media, and the role of the workplace. The contrast thing happens to the Australian student who tends to think that there are a lot more changes that need to be done in related to the Indonesian educational system. For instance, she stated that there must be more easiness in getting the credit transfer on the college subjects.

Both Australian student and Kazakhstani student have low level of satisfaction on Indonesian educational system as shown in the table chart with grade of 2 and 3 as compared to the right box. Actually, their low level of satisfaction on Indonesian educational system is mostly affected by their cultural background which tends to gain high expectation on the technological thingy. They expect that every need related to the academic rules had been done simply and technology-based. For instance, when it comes to do the research for their thesis, they still need to ask for the permission and recommendation letter manually in the academic office.

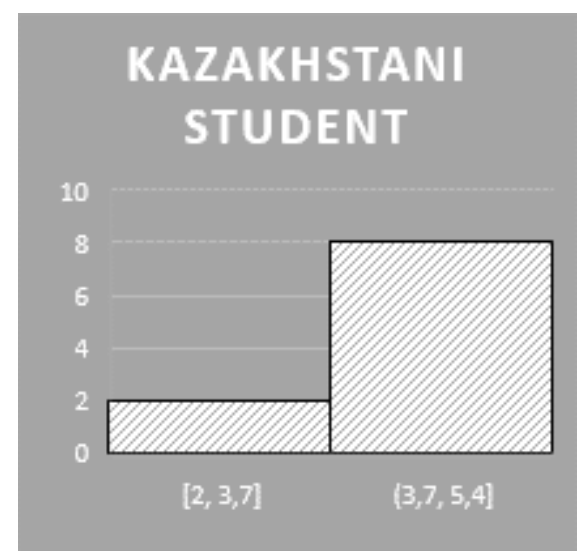

\section{NB: Left Box (The Level of Satisfaction on Educational System) - Right Box (Personal Values)}

*Kazakhstani student's not having a good expectation to Indonesian education system 


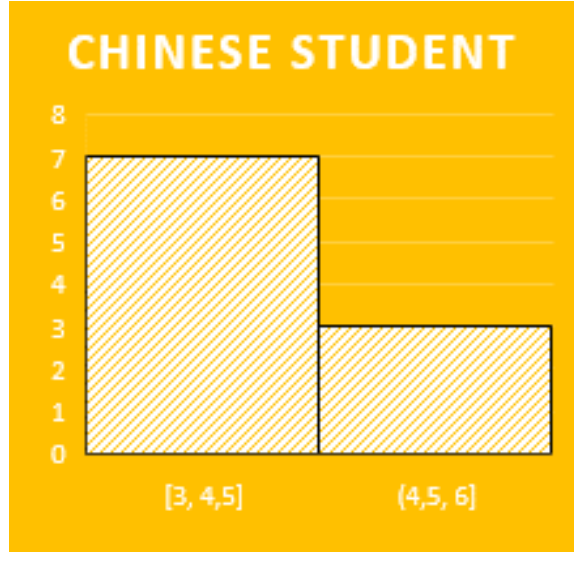

NB: Left Box (The Level of Satisfaction on Educational System) - Right Box (Personal Values)

*Student from China said that she can take Indonesian educational system for granted

\section{Kazakhstani and Chinese} Student (S2 Literature and Cultural Studies)

The first thing that jumps into the Kazakhstani's student soon after she has arrived in Indonesia is that she feels pretty impressed with the friendliness of Indonesian people. All her classmates are very helpful and tend to give her more space in adapting with the new culture and new environment. She also said that her friends are really helpful in helping her coming up with some of the subjects in class. For the example, she feels really comfortable when she had to work together with the local students in doing presentation in class. The communication runs well.
Furthermore,based on the basic understanding on personal values, including the differences between values, beliefs, and attitudes; Kazakhstani student tends to have more knowledge than her Chinese partner. But again, it does not affect on the level of pride of her nationality as she's really proud of the values of her country as well as know well about the traditional culture in China. Moreover, there are two most substantial things which influence her current life: the role of her family life and the role of the technology. Again, as one of the most influential countries in the world; China has lead to the modern advanced technology so that its people consider that technology has become one of the most essential parts in their life. During the 1930s, China had ever faced great economic depression which later influences on how its people going on with their life and so does this Chinese student.

As her family has such great expectation to her education, the role of the educational background holds an important part for her to build her perspective in seeing the world. For more, she had been passed the darkest time in her life when she lost her beloved father at the age of ten and continued by losing job when her mother needs her to help their family keep survive. These two tragic events have completely changed the way she thinks and 
the way she sees life, that life is full of struggle and never been that easy. And what is less important for her life including the role of her religion, workplace, friends, and media.

Because of her hard experience in life, this Chinese student tends to think that she must become a strong woman in order to be able to keep standing in her own feet. And one way to actualize her dream is by having the highest education. After all that she experienced, all things that she can think of and focus is about finishing her master degree with the best grade. This is one reason why she does not pay too much attention to the institutional education system. She can take it for granted. This is shown in the table chart with the grade of 7 which means that she has high level of satisfaction on the Indonesian educational system.

For more, for the Kazakhstani student; the role of her family life, educational background, and the role of the media (social media, television, and movies) are quite essential to build her character, attitude, and value. She comes from highly educational family with a father who becomes a doctor and a mother who becomes a scientist. That is why; her parents sent her away to Indonesia in order to support her choice on education and give her the best gift for her brightest future. And one important reason which makes her to reach her dream by taking higher education is that she wants to be able to educate the society especially about how the real role of the media is and how the media is being constructed by the capitalists for the sake of their own benefits. There is no neutral media so that she feels that she's got the responsibility to right the wrong.

Meanwhile, the roles of friends, technology, workplace, and some historical events in her country do not even really effect on her current life. All of these are because she prefers to get busy with developing and encouraging herself to be useful to others rather than focusing on what people said about her life. And since she has no terrible experience with some significant life events, she does not feel that there is any change to be done on the way she goes on with her life. Even though there are some differences between the Indonesian educational system and the educational system in her country, she thinks that she can achieve on how the institutional education system works especially on how she likes her new Indonesian friends and lecturers. The lecturers and the academic staffs are really helpful when she has problems related to the college subjects, the academic grades, or even about her communication skills.

Overall, all of those international students have agreed that the campus life 
in Airlangga University is incredibly great. Those students are greatly impressed with the friendliness of Indonesian people who are very welcome since the first day they come to study in a college. They also said that most of the Indonesian people are very helpful and very kind even to the stranger. This is one great reason why they love studying in Indonesia and why they have such great personal experience in communicating and interacting with Indonesian people. Some of them said that they also love Indonesian culture and tradition which is very unique, while some others said that they love the traditional Indonesian food like nasigoreng (fried rice), gado-gado, rendang, and sate ayam (chicken satay).
From the discussion above, it can be generally concluded that personal values have a positive effect on influencing the level ofsatisfaction on institutional education system among those international students in Faculty of Humanity - Airlangga University. Personal values which include some basic things like religion, family life, friends, educational background, media, historical events, and some significant life events tend to have such massive influence on the way someone sees the whole world and the way someone is enable to build their own character, attitude, and belief. Once it grows, it will greatly impact on someone's perspective and how she or he becomes the person she or he is now. 



\section{CONCLUSION}

As a matter of fact, international education is considered to be a raising phenomenon worldwide because the internationalization of higher education is one response to the driving force of globalization (Van Der Wende, 2007). For more, the international students tend to share a number of certain characteristics based on their personal background. What the international students see, expect, and express might be quite different from those local students as they are facing a lot of cultural differences including the difference in institutional education system and value.

Personal value of the international students is not only about some guidance on their lives to any decisions that they make and how they are facing their lives, but it is also more about how these personal values can have such big influence to many of the judgments they make. Personal values may depend on something like the choice of the way someone will live their lives, family life, religion, culture and tradition, educational background, workplace environment, some historical events (economic crisis, what happens to our country), some significant life events (divorce, death, losing jobs, financial losses, marriage, etc), the influence on media, friends, and technology.
There are many studies that have been discussed about the role of these international students in certain institutions or universities. This study aims to fulfil the needs on cultural studies field to examine more about the relationship between personal values and the level of satisfaction of the institutional education system among international students in Faculty of Humanity - Airlangga University. Based on the research questions, the result of the discussion shows the following points:

From the perspective of the relationship between personal values and the level of satisfaction on educational system, it can be said that all of those international students have agreed that the campus life in Airlangga University is incredibly great. Those students are greatly impressed with the friendliness of Indonesian people who are very welcome since the first day they come to study in a college. They also said that most of the Indonesian people are very helpful and very kind even to the stranger. This is one great reason on why they have such great personal experience in communicating and interacting with Indonesian people. Even though some of them admit that they are still facing some difficulties in dealing with Indonesian educational system, they seem not want to change or fix any of those systems. 
And when it comes to handle their difficulties in understanding English to learn better about Bahasa Indonesia, they feel quite satisfied with the help of the lecturers, friends, and the academic staffs. Some of them, especially those who come from non-English speaking countries (Chinese and Kazakhstani students from Literature and Cultural Studies as well as that Serer student from Indonesian Department), feel that they can improve their ability to speak English once they are taking their college in Faculty of Humanity, Airlangga University because of the assistance from both the lecturers and their friends.

And from the table chart that has been shown above, it can be stated that personal

\section{REFERENCES}

Arambewela\& Hall. 2011. The Role of Personal Values in Enhancing Student Experience and Satisfaction among International Postgraduate Students: An Exploratory Study. Paper presented at the International Conference on Education and Educational Psychology (ICEEPSY 2011), Turkey.

Benos N \&Zotou S. 2014. Education and Economic Growth: A MetaRegression Analysis. World Dev. 2014; 64: 669-689. values have a positive effect on influencing the level ofsatisfaction on institutional education system among those international students in Faculty of Humanity - Airlangga University. Some of those international students said that they are not too satisfied with the Indonesian educational system, whereas some of the rest are said differently. Practically, both personal values and the level of satisfaction on institutional education system have its own role in influencing one's perspective and personal characters including how one can take and deal with some different cultures in the right way.

Bhandari \& Blumenthal. 2009. Global Student Mobility: Moving Towards Brain Exchange. In R. Bhandari \& S. Laughlin (Eds.), Higher Education on the Move: New Developments in Global Mobility (pp. 1-15). New York: AIFS Foundation.

Bilsky W \& Schwartz, S.H. 2009. Values and Personality. Eur J Pers. 2009; 8: 163-181.

Brutt-Griffler, J. 2002. World English. Clevedon: Multilingual Matters.

Crystal, D. 2003. English as a Global Language (second edition). 
Cambridge: Cambridge University Press.

Ferssizidis P, Adams LM, Kashdan TB, Plummer C, Mishra A, Ciarrochi J. 2010. Motivation and Commitment to Social Values: The Roles of Age and Gender. MotivEmot. 2010; 34: 354362.

Hair JF, Black WC, Babin BJ, Anderson RE. 2010. Multivariate Data Analysis: A Global Perspective. Pearson Prentice Hall: New Jersey. Jamaludin NL, Sam DL, Sandal GM, Adam AA. 2016. The Influence of Perceived Discrimination, Orientation to Mainstream Culture and Life Satisfaction on Destination Loyalty Intentions: The Case of International Students. Curr Issues Tour.

Jenkins, J. 2003. World Englishes. London: Routledge.

Kachru, B. (ed.). 1992. The Other Tongue (second edition). Urbana and Chicago: University of Illinois Press.

Mair, C. (ed.). 2003. The Politics of English as a World Language. Amsterdam: Rodopi.

Massey J \& Burrow J. 2012. Coming to Canada to Study Factors that Influence Students Decisions to Participate in International Exchange. J Stud Aff Res Pract. 2012; 49: 83-100.
Mauranen, A. 2009. Academic English as a Lingua Franca - A Corpus Approach. TESOL Quarterly 37: 513527.

Sanchez CM, Fornerino M, Zhang $\mathrm{M}$. 2006. Motivations and the Intent to Study Abroad among US, French, and Chinese Students. J Teach Int Bus. 2006; 18: 27-52.

Schwartz SH. 2009. Culture Matters: National Value Cultures, Sources and Consequences. In: Wyer RS, Chiu C, Hong Y. Understanding Culture: Theory, Research and Application. New York: Psychology Press; 2009. pp. 127-150.

Seidlhofer, B. 2005. Closing a Conceptual Gap: The Case for a Description of English as a Lingua Franca. International Journal of Applied Linguistics 11: 133-158. 